\title{
EFEKTYWNOŚĆ WARUNKOWEGO UMORZENIA POSTĘPOWANIA KARNEGO W POSTĘPOWANIU PRZYGOTOWAWCZYM I JURYSDYKCYJNYM
}

Warunkowe umorzenie postępowania karnego jest oryginalnym polskim środkiem poddania sprawcy próbie, polegającym na czasowym odroczeniu wydania rozstrzygnięcia co do winy i odpowiedzialności karnej sprawcy ${ }^{1}$.

W literaturze podkreśla się, że celem stosowania środków probacyjnych jest realizacja zakładanych funkcji kary w sposób najbardziej efektywny, zarówno z punktu widzenia prewencji indywidualnej, rozwiązania konfliktu wywołanego przestępstwem, jak i prewencji ogólnej ${ }^{2}$. W ocenie efektywności probacji zwraca się uwagę, że dzięki pozostawieniu sprawcy na wolności unika się nie tylko niebezpieczeństwa jego demoralizacji, jakie stwarza skupienie przestępców w zakładzie karnym, ale również sprawca przez wykonywanie pracy w warunkach wolnościowych ma lepsze możliwości łożenia na utrzymanie rodziny oraz naprawienia szkody lub spłacenia odszkodowań za szkody wyrządzone przestępstwem ${ }^{3}$.

Mikołaj Leonieni i Wojciech Michalski słusznie wskazuja, że efektywność warunkowego umorzenia postępowania karnego to stosunek pomiędzy celami (zadaniami) przepisów o badanej instytucji a ich realizacja, tj. wynikami ich stosowania w praktyce sądowej ${ }^{4}$. Cytowani autorzy ponadto wyróżniają efektywność w najszerszym i najwęższym znaczeniu. Efektywność w najszerszym znaczeniu wiąże się z takim ukształtowaniem samego orzeczenia, aby oddziaływało na sprawcę czynu przestępnego oraz na jego otoczenie również po upływie okresu próby. Natomiast najwęższe ujęcie dotyczy przyjmowania niekiedy już samego faktu niepodjęcia warunkowo umorzonego postępowania w okresie

${ }^{1}$ W. Wróbel, A. Zoll, Polskie prawo karne. Część ogólna, Kraków 2013, s. 476.

${ }^{2}$ Ibidem, s. 472; por. A. Zoll, Środki zwiazane z poddaniem sprawcy próbie, w: idem (red.), Kodeks karny. Część ogólna. Komentarz do art. 1-116 k.k., Warszawa 2012, s. 913 oraz cyt. tamże A. Bałandynowicz, Probacja. System sprawiedliwego karania, Warszawa 2002, s. 255 i n.; E. Bieńkowska, Środki zwiazane z poddaniem sprawcy próbie, w: G. Rejman (red.), Kodeks karny. Część ogólna. Komentarz, Warszawa 1999, s. 988 i n.; G. Łabda, Środki zwiqzane z poddaniem sprawcy próbie, w: J. Giezek (red.), Kodeks karny. Część ogólna. Komentarz, Warszawa 2007, s. 489.

${ }^{3}$ M. O. Warren, Correctional Treatment in Community Settings: A Report of Current Research, Washington 1972, cyt. za: A. Marek, Rola amerykańskiej probacji i jej efektywność, „Acta Universitatis Nicolai Copernici - Ekonomia; Wydział Nauk Ekonomicznych i Zarządzania Uniwersytetu im. Mikołaja Kopernika w Toruniu" 1978, Prawo XVI, z. 89, s. 226.

${ }^{4}$ M. Leonieni, W. Michalski, Efektywność warunkowego umorzenia postępowania karnego w praktyce sqdowej, Warszawa 1975, s. 44. 
próby, niezależnie od wykonywania lub niewykonywania nadzoru i niezależnie od społecznego lub aspołecznego zachowania się sprawcy czynu przestępnego ${ }^{5}$.

Konstrukcja efektywności przedmiotowej instytucji w koncepcji Leonieniego i Michalskiego jest trójstopniowa: wyznaczona przez pomyślny upływ okresu próby, niepopełnienie nowego przestępstwa i społeczne efekty warunkowego umorzenia. Do powyższego katalogu cytowani autorzy dołączają szybkość i sprawność postępowania sądowego oraz organizacje pracy organów wymiaru sprawiedliwości ${ }^{6}$.

Witold Ciechanowicz wskazuje, że warunkiem efektywności warunkowego umorzenia postępowania karnego jest prawidłowe stosowanie tej instytucji. Uważa on, że decyzje takie powinny zapadać zgodnie ze wskazówkami ustawy tylko w odniesieniu do ściśle określonych czynów i w stosunku do ściśle określonych sprawców ${ }^{7}$.

Mając na uwadze powyższe, należy przedstawić własną propozycję zdefiniowania efektywności instytucji warunkowego umorzenia postępowania karnego jako zrealizowanie celów ustawodawczych wprowadzenia tej instytucji przez właściwe ukształtowanie rozstrzygnięć i decyzji procesowych w toku postępowania, których wykonanie w indywidualnych sprawach zmierza do pomyślnego zakończenia okresu próby oraz okresu wskazanego w art. 68 § k.k.

W literaturze przedmiotu miernik efektywności jest określany zarówno przez udany bądź nieudany przebieg lub zakończenie okresu próby ${ }^{8}$, brak powrotności do przestępstwa ${ }^{9}$ lub określenie stopnia resocjalizacji sprawcy w zakresie utrwalenia właściwej postawy społecznej i przestrzegania porządku prawnego ${ }^{10}$.

W badaniach własnych 405 spraw dotyczacych efektywności warunkowego umorzenia postępowania karnego mierzono przedmiotową efektywność z punktu widzenia sposobu zakończenia okresu próby; poprzedzono je analizą w szczególności wyników badań przeprowadzonych przez Andrzeja Zolla ${ }^{11}$, a także Mikołaja Leonieniego i Wojciecha Michalskiego ${ }^{12}$ w pełnym zakresie

5 Ibidem, s. 39-40

6 Ibidem, s. 44-45.

${ }^{7}$ W. Ciechanowicz, Efektywność warunkowego umorzenia postepowania karnego w praktyce prokuratury wojskowej, „Wojskowy Przegląd Prawniczy” 1978, nr 2, s. 213.

8 A. Kordik, Warunkowe zawieszenie wykonania kary w systemie środków probacyjnych $i$ jego efektywność, Wrocław 1998, s. 139; W. Ciechanowicz, op. cit., s. 220-221; L. Bogunia, W. Rodakiewicz, Problemy wykonywania warunkowego umorzenia postepowania karnego, „Nowa Kodyfikacja Prawa Karnego", t. 16, 2004, s. 203; M. Leonieni, W. Michalski, op. cit., s. 6-7, 44-45; A. Marek, Rola..., s. 223 i 224.

${ }^{9}$ A. Kordik, op. cit., s. 9; M. Heine, Warunki efektywności resocjalizacji nieletnich poddanych dozorowi sqdowych kuratorów społecznych, Wrocław 1982, s. 63; por. A. Marek, Rola..., s. 211229 oraz K. Hamai et al. (eds.), Probation Round the Word. A Comparative Study, London-New York 1995, cyt. za: A. Marek, Prawo karne, Warszawa 2011, s. 295; W. Ciechanowicz, op. cit., s. 220-221; M. Leonieni, W. Michalski, op. cit., s. 6-7, 44-45; E. Skrętowicz, Problem efektywności i sprawności wykonania kary ograniczenia wolności, „Palestra” 1976, nr 12, s. 42-43.

10 A. Marek, Rola..., s. 223-224; M. Leonieni, W. Michalski, op. cit., s. 6-7 i 44-45.

11 A. Zoll, Materialnoprawna problematyka warunkowego umorzenia postepowania karnego, „Zeszyty Naukowe Uniwersytetu Jagiellońskiego. Prace Prawnicze”, z. 62, Warszawa-Kraków 1973.

12 M. Leonieni, W. Michalski, op. cit. 
tytułowej problematyki, przez Arnolda Gubińskiego i Zenona Welfelda ${ }^{13}$, jak również przez Witolda Ciechanowicza ${ }^{14}$ w zakresie kształtu orzeczenia warunkowo umarzającego postępowanie karne w trakcie obowiązywania kodyfikacji karnych z 1969 r. oraz badań Tomasza Kozioła ${ }^{15}$ w pełnym zakresie tytułowej problematyki na gruncie obowiązującego stanu prawnego z $1997 \mathrm{r}^{16}$

Celem artykułu jest przedstawienie wyników badań własnych i innych autorów dotyczacych warunkowego umorzenia postępownia karnego i jego efektywności w postępowaniu przygotowawczym i jurysdykcyjnym w przedmiocie zastosowania niniejszej instytucji. Prezentacja wyników badań własnych zostanie przeprowadzona za pomocą czynników zwiększających i zmniejszających badaną efektywność opisujących tytułową problematykę badawcza $\mathrm{w}$ ujęciu prawa materialnego i prawa procesowego z uwzględnieniem ustawy z 27 września 2013 r. o zmianie ustawy - Kodeks postępowania karnego oraz niektórych innych ustaw (Dz. U. 2013, poz. 1247). Wybór niniejszych czynników został dokonany przez analizę obowiązujących przepisów prawnych, krytyczny przegląd literatury przedmiotu oraz wyniki analizy badań własnych 405 spraw wylosowanych metodą losowania zespołowego wieloetapowego ${ }^{17}$, dotyczaccych efektywności instytucji warunkowego umorzenia postępowania karnego, opatrzonych sygnatura postępowań prowadzonych w 6 powszechnych jednostkach organizacyjnych sądownictwa, należących do obszaru właściwości Sądu Okręgowego w Krakowie, wszczętych w okresie od 1 lipca 2003 r. do 1 lipca 2009 r. z punktu widzenia 5 sytuacji procesowych związanych ze sposobem zakończenia okresu próby (pomyślne zakończenie okresu próby, postanowienie o niepodejmowaniu warunkowo umorzonego postępowania karnego, postanowienie o podjęciu warunkowo umorzonego postępowania karnego, postanowienie o umorzeniu postępowania wykonawczego z powodu upływu okresu próby oraz okresu wskazanego w art. $68 \S 4 \mathrm{k} . \mathrm{k}$., postanowienie o umorzeniu postępowania wykonawczego z powodu śmierci oskarżonego). Pierwszy etap badań polegał na określeniu trzech warstw (miejsca, czasu, zakresu) stanowiących materiał do drugiego etapu losowania, tzw. prostego losowania warstwowego. Ten drugi etap - tzw. proste losowanie warstwowe - polegał na tym, że każda ze spraw znajdujacca się w poszczególnej „warstwie” mogła być wylosowana, i to z jednakowym prawdopodobieństwem. Tytułowa problematyka zostanie przedstawiona poprzez kolejne etapy postępowania karnego.

Analizowaną problematykę zaprezentowano za pomocą czynników rozumianych jako każda aktywność organów postępowania w przedmiocie stosowania badanej instytucji, mająca wpływ na efektywność instytucji warunkowego umorzenia postępowania karnego. Uwzględnienie czynników zwiększających

13 A. Gubiński, Z. Welfeld, Oceny spraw o drobne kradziė̇e umorzonych z mocy art. 27 k.k. i art. 26 \$ 1 k.k. (Wyniki badań aktowych), „Państwo i Prawo” 27, 1976, z. 8-9, s. 153-168.

${ }_{14}$ W. Ciechanowicz, op. cit., s. 211-222.

15 T. Kozioł, Mechanizmy selekcji w stosowaniu warunkowego umorzenia postepowania karnego, (rozprawa doktorska obroniona na WPiA UJ), Kraków 2007.

${ }^{16}$ K. Juszka, Stan badań nad efektywnościa instytucji warunkowego umorzenia postepowania karnego przez pryzmat sposobu zakończenia okresu próby, w: S. Pikulski, M. Romańczuk-Grącka, B. Orłowska-Zielińska, Tożsamość prawa karnego, Olsztyn 2011, s. 670-677.

17 R. Zasępa, Metoda reprezentacyjna, Warszawa 1972, s. 17 i 23. 
efektywność omawianej instytucji oraz natychmiastowa reakcja na czynniki ją obniżające bezpośrednio zmierza do pomyślnego zakończenia okresu próby i okresu wskazanego w art. 68 § 4 k.k.

Badania własne aktualizują i poszerzaja dotychczasowy stan badań o analizę postanowień o umorzeniu postępowania wykonawczego z powodu upływu okresu wskazanego w art. $68 \S 4$ k.k., postanowienia o umorzeniu postępowania wykonawczego z powodu śmierci oskarżonego oraz specyfiki postanowienia o niepodejmowaniu warunkowo umorzonego postępowania karnego także z punktu widzenia kształtu prawomocnego wyroku warunkowo umarzającego postępowanie karne.

Pierwszym czynnikiem zwiększającym efektywność warunkowo umorzonego postępowania karnego i zarazem aktualnym problemem badanej instytucji jest wieloaspektowa analiza wyjaśnień podejrzanego złożonych w toku postępowania przygotowawczego. W 49 z 405 obejmujaccych badania własne spraw pełne skruchy nastawienie przesłuchiwanego w charakterze podejrzanego było powiązane $\mathrm{w}$ analizowanych wyjaśnieniach $\mathrm{z}$ całkowitym przyznaniem się podejrzanego do winy. Wskazana postawa prowadziła do pomyślnego zakończenia okresu próby oraz okresu wskazanego w art. 68 § 4 k.k. Występująca w badaniach własnych przeciwstawna do zaprezentowanej wyżej postawa powinna uzasadniać szczególną czujność organów postępowania, stosujących badaną instytucję realizowaną w szczególności przez częstsze zasięganie wywiadów środowiskowych.

Na aprobatę zasługuje ponadto podkreślona w badaniach własnych praktyka nieuzależniania wydania wyroku warunkowo umarzającego postępowanie karne oraz sposobu zakończenia okresu próby od przyznania się sprawcy do zarzucanego czynu, także przy częściowym przyznaniu się sprawcy do zarzucanego czynu oraz późniejszych modyfikacjach w tym zakresie.

Następnym czynnikiem zwiększajacym efektywność niniejszej instytucji jest stosowanie instytucji porozumienia między sprawcą a pokrzywdzonym w trybie art. $66 \S 3 \mathrm{k} . \mathrm{k}$. oraz art. $341 \S 3 \mathrm{k} . p . \mathrm{k}$.

Stosowanie art. $66 \S 3$ k.k. jest związane z wystapieniem okoliczności powstałych po popełnieniu przestępstwa, które nie zastępują przesłanek wymienionych w art. $66 \oint 1 \mathrm{k} . \mathrm{k}$., ale uzupełniaja j je $\mathrm{e}^{18}$. W literaturze wskazuje się, że omawiane okoliczności są od siebie wzajemnie niezależne w tym znaczeniu, iż naprawienie szkody lub uzgodnienie sposobu jej naprawienia może się odbyć bez pojednania między sprawcą a pokrzywdzonym i na odwrót ${ }^{19}$. Zwraca się

18 T. Kozioł, op. cit., s. 93-94; por. A. Zoll, w: idem (red.), Kodeks..., s. 921; A. Zoll, „Drobna przestepczość" jako problem dogmatyki prawa karnego i polityki karnej, w: J. Czapska et al. (red.), Zasady procesu karnego wobec wyzwań wspótczesności. Księa ku czci Profesora Stanisława Waltosia, Warszawa 2000, s. 455; D. Kużelewski, Wptyw prawa karnego materialnego na mediacje między pokrzywdzonym i oskarżonym - wybrane aspekty, w: Z. Ćwiąkalski, G. Artymiak (red.), Wspótzależność prawa karnego materialnego i procesowego, Warszawa 2009, s. 352-353; A. Zoll, Założenia polityczno-kryminalne kodeksu karnego w świetle wyzwań wspótczesności, „Państwo i Prawo" 53, 998, z. 9-10, s. 49; D. Gorzkiewicz, Warunkowe umorzenie postepowania karnego w praktyce (uwagi de lege ferenda do art. 66 § 3 k.k.), „Wojskowy Przegląd Prawniczy” 2007, nr 4, s. 61-62.

19 T. Kozioł, op. cit., s. 226; por. W. Wróbel, A. Zoll, op. cit., s. 480; W. Daszkiewicz, Pojedna- 
także uwagę, że pojednanie może zależeć od naprawienia szkody lub ustalenia warunków jej naprawienia ${ }^{20}$.

Krzysztof Nowicki słusznie wskazuje, że zadaniem art. 341 § 3 k.p.k. jest stworzenie możliwości oskarżonemu i pokrzywdzonemu zminimalizowania we własnym zakresie skutków wcześniejszego działania oskarżonego, dochodzenia roszczeń przez pokrzywdzonego w sposób stosunkowo szybki bez potrzeby czekania do końca procesu, a często nawet do dalszego procesu cywilnego ${ }^{21}$.

W badaniach Kozioła, w 86 z 565 spraw, w których wystapił zindywidualizowany pokrzywdzony, akta wskazywały na zaistnienie pojednania pomiędzy pokrzywdzonym a sprawca lub na uzgodnienie przez nich sposobu naprawienia szkody, a w 99 przypadkach na naprawienie szkody przed wydaniem orzeczenia.

Badania własne wskazują na stosowanie w 9 z 405 spraw porozumienia z art. $66 \S 3 \mathrm{k} . \mathrm{k}$. W $5 \mathrm{z}$ nich porozumienie zawarto między sprawcą i pokrzywdzoną osobą prawna, a w 4 sprawach pokrzywdzonym była osoba fizyczna. W 5 przedmiotowych sprawach niewpłacona kwota zobowiąania do naprawienia szkody, zawarta w porozumieniu między sprawca a pokrzywdzona osobą prawną w postępowaniu przygotowawczym, była włączana przez sąd do wyroku warunkowo umarzajacego postępowanie karne. W żadnej ze spraw objętej badaniami własnymi nie doszło do przerwy lub odroczenia posiedzenia albo rozprawy w celu umożliwienia oskarżonemu i pokrzywdzonemu porozumienia się w kwestii naprawienia szkody lub zadośćcuczynienia w trybie art. $341 \S 3$ k.p.k.

Analiza niniejszych spraw prowadzi do zasadności postulatów: wprowadzenia pisemnej formy zawierania porozumienia, włączania jego treści do omawianego wyroku i nowelizacji art. $68 \S 2 \mathrm{k} . \mathrm{k}$. przez dodanie do katalogu tego przepisu uchylania się od wykonania niniejszego porozumienia. Wprowadzenie przedmiotowych postulatów przeciwdziała występującemu w praktyce podważaniu przez sprawcę postanowień porozumienia $\mathrm{w}$ toku postępowania karnego z powodu ustnej formy jego zawarcia.

Zmiany $\mathrm{w}$ zakresie istoty i kształtu art. $66 \mathrm{k} . \mathrm{k}$. wraz z powiąanym z nim art. 59a k.k. ${ }^{22}$ wprowadzonymi art. 12 pkt 1 i 2 ustawy z 27 września

nie, ugoda, mediacja $w$ procesie karnym. Zagadnienia procesowe, w: B. Kubiak, M. Romanowski (red.), Nowa kodyfikacja karna. Krótkie komentarze. Kodeks postęowania karnego, z. 8, Ministerstwo Sprawiedliwości. Departament Kadr i Szkolenia, Warszawa 1998, s. 60, cyt. za: K. Nowicki, Wptyw pojednania oskarżonego (podejrzanego) z pokrzywdzonym na warunkowe umorzenie postepowania, „Nowa Kodyfikacja Prawa Karnego”, t. 4, 1999, s. 203-204; E. A. Wdzięczna, Warunkowe umorzenie postepowania karnego a postulaty restorative justice - wybrane zagadnienia, w: G. Rejman et al. (red.) Problemy prawa i procesu karnego. Księga poświęcona pamięci Profesora Alfreda Kaftala, Warszawa 2008, s. 336.

${ }^{20}$ M. Płatek, Wstep I, czyli o miejscu i roli sprawiedliwości naprawczej $w$ systemie sprawiedliwości karnej, w: eadem, M. Fajst (red.), Sprawiedliwość naprawcza. Idea. Teoria. Praktyka, Warszawa 2005, s. 17, cyt. za: D. Kużelewski, op. cit., s. 354.

${ }^{21} \mathrm{~K}$. Nowicki, Wybrane zagadnienia z zakresu warunkowego umorzenia postepowania na posiedzeniu przed rozprawa gtówna $w$ świetle przepisów nowego k.p.k., „Nowa Kodyfikacja Prawa Karnego", t. 3, 1998, s. 142-143.

${ }_{22}$ Zob. http://legislacja.rcl.gov.pl/docs//2/194900/194903/194904/dokument96306.pdf, s. 25 [dostęp: 10.09.2014]; http://bip.ms.gov.pl/pl/projekty-aktow-prawnych/prawo-karne/download,1649,1. html, s. 200-201 [dostęp: 10.09.2014]. 
2013 r. o zmianie ustawy - Kodeks postępowania karnego oraz niektórych innych ustaw (Dz. U. 2013, poz. 1247) sa wynikiem szerokiej dyskusji ${ }^{23}$ w przedmiocie konsekwencji prawnych wydania postanowienia o podjęciu warunkowo umorzonego postępowania karnego oraz propozycji ograniczenia stosowania warunkowego umorzenia postępowania karnego lub zastapienia tej instytucji inną instytucją reakcji na popełnione przestępstwo. Wyniki analizy omawianych badań własnych stanowią podstawę do umiarkowanej krytyki niniejszych rozwiązań ustawowych. Z jednej strony słusznie zrezygnowano z przesłanki uzgodnienia między sprawca a pokrzywdzonym sposobu naprawienia szkody z obowiązującego art. $66 \S 3$ k.k. oraz wprowadzono art. 59a $§ 2$ k.k. Z drugiej - należy podkreślić, że jedna z przyczyn braku efektywności jest brak ustawowego określenia konieczności przedłożenia potwierdzenia naprawienia szkody lub zadośćuczynienia za doznaną krzywdę w formie pisemnej, które w praktyce stosowania może być zasadnym argumentem o możliwości nacisków sprawcy na złożenie wniosku przez pokrzywdzonego.

Ważnym czynnikiem zwiększającym efektywność badanej instytucji jest wprowadzenie wzmianki o postanowieniach ugody do wyroku warunkowo umarzającego postępowanie karne także w celu synchronizacji z treścia art. $68 \S 2 \mathrm{k} . \mathrm{k}$. W literaturze podkreśla się, że mediacja daje możliwość szybkiego zadośćuczynienia za wyrządzoną krzywdę czy doznaną szkodę, przejęcia przez sprawcę odpowiedzialności za czyn, którego się dopuścił, zaniku anonimowości pokrzywdzonego oraz upodmiotowienia stron konfliktu, które staja się gospodarzami, partnerami w rozmowie ${ }^{24}$.

${ }^{23}$ Przykładowo: Kolokwium Bielańskie 2012 - zapis dyskusji podczas IX Bielańskiego Kolokwium Karnistycznego, „Środki związane z poddaniem sprawcy próbie”, Warszawa, 16 maja 2012 r., umieszczony na stronie internetowej „Czasopisma Prawa Karnego i Nauk Penalnych”: http://www.czpk.pl/2012/05/18/zapis-video-ix-bielanskiego-kolokwium-karnistycznego-2012/ [dostęp: 10.09.2014]; IX Bielańskie Kolokwium Karnistyczne, „Środki zwiqzane z poddaniem sprawcy próbie”, Warszawa, 16 maja 2012 r. - zapis dyskusji, w: J. Majewski (red.), Środki zwiqzane $z$ poddaniem sprawcy próbie. Pokłosie IX Bielańskiego Kolokwium Karnistycznego, Toruń 2013, s. 157-159; Zebrania Naukowe Katedry Prawa Karnego umieszczone na stronie internetowej „Czasopisma Prawa Karnego i Nauk Penalnych”: http://www.czpk.pl/2011/12/23/komentarz-online-zebranie-naukowe-katedry-prawa-karnego-uj-nowelizacja-czesci-ogolnej-kodeksu-karnego/ [dostęp: 10.09.2014].

${ }^{24}$ A. Rękas, Korzyści sprawiedliwości naprawczej dla osoby pokrzywdzonej przestepstwem z punktu widzenia sędziego, w: Materiały międzynarodowej konferencji pt. „Mediacja w sprawach karnych jako instytucja dla pokrzywdzonego", zorganizowanej przez Ministerstwo Sprawiedliwości RP, Instytut Nauk Prawnych Polskiej Akademii Nauk oraz Polskie Centrum Mediacji w Warszawie $w$ dniach 7-8 grudnia 2009 r., wyd. 1, Ministerstwo Sprawiedliwości, Warszawa 2010, s. 29-30 i 33; por. E. Bieńkowska, Pojednanie środkiem polityki karnej, „Jurysta” 1995, nr 10, s. 13 i n.; eadem, Mieszkańcy Warszawy o przestępczości i karaniu za przestępstwa (refleksje na tle wyników badania ankietowego), „Przegląd Więziennictwa Polskiego” 1997, nr 14, s. 50 i n., cyt. za: E. Bieńkowska, Istota i znaczenie mediacji w prawie karnym, w: O. Górniok (red.), U progu nowych kodyfikacji karnych. Księga pamiatkowa ofiarowana Profesorowi Leonowi Tyszkiewiczowi, Katowice 1999, s. 25; A. Rękas, Mediacja w teorii i praktyce, w: Ks. A. Gretkowski, D. Karbarz (red.), Mediacja $w$ teorii i praktyce, Stalowa Wola 2009, s. 155; A. Rękas, Mediacja w Polsce na tle doświadczeń państw Unii Europejskiej, w: Konferencje i Seminaria 4(48)03, Mediacja w krajach Unii Europejskiej $i$ w Polsce, Materiaty z seminarium dla postów Sejmu IV kadencji, zorganizowanego 28 kwietnia 2003 r. przez sejmowa Komisję Sprawiedliwości i Praw Człowieka, Biuro 
Z prezentacji wyników badań Kozioła wynika, że na 793 badane sprawy w $718(99,3 \%)$ nie przeprowadzono postępowania mediacyjnego. W trakcie badań własnych stwierdzono, że w 405 sprawach przeprowadzono 48 mediacji: 47 zakończyło się ugoda, a jedna nie powiodła się. W obu powoływanych badaniach nie przeprowadzono postępowania mediacyjnego w postępowaniu przygotowawczym.

Ugoda postępowania mediacyjnego, stanowiąc załącznik do pisemnego sprawozdania z przeprowadzonego postępowania mediacyjnego, powinna być mierzalna, aktualna, konkretna, realistyczna, określona (MAKRO) ${ }^{25}$.

W świetle powyższego za trafne należy uznać zmiany art. $107 \S 3$ k.p.k. opisane w 1 pkt 35 powołanej wyżej ustawy z 27 września 2013 r. w zakresie zrównania ugody postępowania mediacyjnego z ugodą zawartą przed sądem, do której stosuje się w trybie obowiąujaccego art. $107 \S 1$ k.p.k. nadanie na żądanie osoby uprawnionej klauzuli wykonalności orzeczeniu podlegajacemu wykonaniu w drodze egzekucji.

$\mathrm{Z}$ punktu widzenia efektywności $\mathrm{w}$ zakresie postępowania mediacyjnego należy postulować na podstawie analizy wyników badań własnych - po pierwsze - obejmowanie ugodą postępowania mediacyjnego obu stron konfliktu.

Pojęcie „objęcie ugodą obu stron postępowania mediacyjnego” jest rozumiane w niniejszych badaniach jako dążenie do osiagnięcia w toku postępowania mediacyjnego relacji między stronami znajdujacych potwierdzenie w postanowieniach ugody zawartej w toku tego postępowania, takich jak: „strony pojednały się”, „strony zobowiąuja się do poprawnego zachowania się względem siebie”, „pokrzywdzeni oświadczaja, że nie mają żadnych pretensji do oskarżonego", „oskarżony przeprosił pokrzywdzona, a pokrzywdzona przeprosiny przyjęła”, „strony pogodziły się, a pokrzywdzony nie żąda od oskarżonego żadnej rekompensaty".

Badania własne 405 spraw pokazuja, że w 26 z 48 spraw, w których przeprowadzono postępowanie mediacyjne, postanowienia ugody, mające skutek przede wszystkim dla oskarżonego, były wcześniej proponowane przez pokrzywdzonych, a oskarżony jedynie akceptował jej warunki. W 22 sprawach przedmiotowymi postanowieniami ugody objęto także pokrzywdzonych. Analizując powyższe, z punktu widzenia efektywności objęcie postanowieniami ugody zarówno oskarżonego, jak i pokrzywdzonego wyraźniej oddaje sposób wykonywania ugody przez oskarżonego oraz co najmniej ogranicza składanie przez pokrzywdzonych nieuzasadnionych wniosków o wszczęcie postępowania o podjęcie warunkowo umorzonego postępowania karnego.

Następną z propozycji zmian w stosowaniu badanej instytucji jest wysuwany $\mathrm{w}$ rozmowie $\mathrm{z}$ mediatorami postulat wydania jednolitego wzoru ugody postępowania mediacyjnego obecnie jako załącznika do rozporządzenia Ministra

Studiów i Ekspertyz Kancelarii Sejmu oraz Polskie Centrum Mediacji, Biuletyn Biura Studiów i Ekspertyz Kancelarii Sejmu, Wydawnictwo Sejmowe, Warszawa 2003, s. 10; D. B. Handler, Violence, fear and communication: the variable impact of domestic violence on mediation, „Mediation Quarterly" 7, 1990, nr 4, s. 331-346; K. Nowicki, op. cit., s. 206.

${ }_{25}$ B. Czarnecka-Dzialuk, D. Wójcik, Głosy uczestników konferencji, w: Materiały międzynarodowej konferencji..., s. 141. 
Sprawiedliwości z 13 czerwca 2003 r. w sprawie postępowania mediacyjnego w sprawach karnych (Dz. U. 2003, Nr 108, poz. 1020 ze zm.) oraz jako załącznika do rozporządzenia Ministra Sprawiedliwości, o którym stanowi art. 23a $\S 8$ znowelizowanego k.p.k. w brzmieniu otrzymanym przez art. 1 pkt 5 ustawy z 27 września 2013 r. o zmianie ustawy - Kodeks postępowania karnego oraz niektórych innych ustaw (Dz. U. 2013, poz. 1247).

Kluczowe czynniki zwiększające przedmiotową efektywność są związane z ukształtowaniem wyroku warunkowo umarzającego postępowanie karne. Prezentacje niniejszych czynników rozpoczyna propozycja nowelizacji dotycząca synchronizacji art. $37 \mathrm{k} . \mathrm{k}$. w zakresie oznaczania w miesiącach i latach - po pierwsze - długości okresu próby (art. 67 § 1 k.k.), po drugie - orzeczonego zakazu prowadzenia pojazdów (art. $67 \S 3$ k.k.).

Analiza wyników badań własnych odnoszących się do stosowania badanej instytucji wskazuje, po pierwsze, na postulat własny wyboru restytucji jako zasady w sposobie nakładania zobowiąania do naprawienia szkody na oskarżonych utrzymywanych przez inne osoby w wyroku warunkowo umarzającym postępowanie karne. Stosowanie niniejszej praktyki przeciwdziała aktualnym wątpliwościom $\mathrm{w}$ kwestii osobistego wykonania omawianych rozstrzygnięć w przedmiotowym wyroku. Przykładem wspomnianych wątpliwości jest treść jednego z uzasadnień wydania postanowienia o niepodejmowaniu przedmiotowego postępowania z powodu wpłaty świadczenia pieniężnego przez matkę oskarżonego.

Jednym z proponowanych kierunków zmian jest propozycja nakładania obowiąku informowania sądu lub kuratora o przebiegu okresu próby w szczególności w sprawach, w których nie oddano oskarżonego pod dozór w wyroku warunkowo umarzającym postępowanie karne.

Ważną z punktu widzenia dowodowego zmianą obecnej praktyki jest także nakładanie obowiązku przeproszenia pokrzywdzonego $\mathrm{w}$ formie pisemnej w przedmiotowym wyroku.

Pierwszym czynnikiem zmniejszającym efektywność warunkowego umorzenia postępowania karnego są przypadki stosowania poręczenia majątkowego $\mathrm{w}$ postępowaniu $\mathrm{w}$ przedmiocie warunkowego umorzenia postępowania karnego. Z jednej strony dyscyplinuje ono sprawcę, a z drugiej - zaburza zasadę indywidualizacji odpowiedzialności karnej oraz utrudnia weryfikację wykonania przedmiotowego wyroku przez oskarżonego. Badania własne 405 spraw wskazuja, że w 2 spośród nich oskarżony czuł się z tego powodu zwolniony $\mathrm{z}$ wykonania wyroku warunkowo umarzającego postępowanie karne w całości lub części, a w kolejnej sprawie stwierdził, że chce wykonać przedmiotowy wyrok, ale nie może tego zrobić z powodu braku pieniędzy.

Kolejnym czynnikiem zmniejszającym efektywność badanej instytucji jest występujące $\mathrm{w}$ obecnej praktyce nieokreślenie terminu i sposobu wykonania obowiązów i środków karnych oraz kierunku wykonania zobowiązania do naprawienia szkody (w całości czy w części) w wyroku warunkowo umarzającym postępowanie karne. 
W literaturze podkreśla się, że z punktu widzenia sprawności i skuteczności orzeczenia przedmiotowy termin powinien być określony konkretna data, uwzględniająca możliwości oskarżonego i interes pokrzywdzonego ${ }^{26}$, a także uwzględniać wyniki porozumienia oskarżonego z pokrzywdzonym, szczególnie w kwestii naprawienia szkody (art. $341 \S 4$ k.p.k.) $)^{27}$.

Trafnie wskazuje Leonieni, stwierdzając, że sąd powinien w orzeczeniu ustalić nie tylko okres próby, ale także termin wykonania zobowiąania. Zdaniem tego autora, jeżeli sąd nie określi tego terminu, zachodzi domniemanie, że jest on równy okresowi próby, a zatem sąd wykonujący orzeczenie nie może następnie własną decyzja, i to na niekorzyść oskarżonego, zmienić treści prawomocnego orzeczenia i ustalić krótszy termin ${ }^{28}$.

Badania innych autorów wskazują na kierunek, termin i sposób wykonania zobowiązania do naprawienia szkody ${ }^{29}$, a także termin i sposób przeproszenia pokrzywdzonego ${ }^{30}$.

Badania własne pokazuja, że w 11 z 53 spraw, w których nałożono zobowiązanie do naprawienia szkody, nie określono terminu i kierunku wykonania, a w 45 na 53 - sposobu jego wpłaty. W odniesieniu do świadczenia pieniężnego w 197 na 328 spraw, w których orzeczono świadczenie pieniężne, nie wskazano terminu, a w 150 na 328 - sposobu jego wpłaty. Analizujacc sposób orzekania przepadku, należy odnotować, że w przestępstwach narkotykowych tylko w 4 z 30 spraw wskazano sposób wykonania przepadku, tj. przez zniszczenie.

Podsumowując, należy podkreślić, że w szczególności przedstawienie w niniejszym artykule teoretycznych i praktycznych aspektów podejmowanych czynników potwierdziło niezbędność badań nad efektywnościa instytucji warunkowego umorzenia postępowania karnego nieprzeprowadzanych pod rządami obecnie obowiąującej Konstytucji RP oraz kodyfikacji karnych z 1997 r. (Kodeks karny, Kodeks postępowania karnego, Kodeks karny wykonawczy). Wieloaspektowa analiza czynników wpływających na przedmiotową

${ }_{26}$ A. Zoll, Materialnoprawna..., s. 184-185; A. Zoll, w: idem (red.), Kodeks..., s. 932; M. Szczepaniec, J. Zygmunt, Obowiazek naprawienia szkody w systemie środków probacyjnych, w: Z. Ćwiąkalski, G. Artymiak (red.), Karnomaterialne i procesowe aspekty naprawienia szkody $w$ świetle kodyfikacji karnych z 1997 r. i propozycji ich zmian, Warszawa 2010, s. 152 oraz cyt. tamże: K. Maksymowicz, Kilka uwag o obowiazku naprawienia szkody w prawie karnym, „Nowa Kodyfikacja Prawa Karnego”, t. 8, 2001, s. 112; T. Kozioł, op. cit., s. 70; Z. Gostyński, Obowiazek naprawienia szkody w nowym ustawodawstwie karnym, Kraków 1999, s. 132 i n., cyt. za: A. Zoll, w: idem (red.), Kodeks..., s. 932; M. Leonieni, W. Michalski, op. cit., s. 69.

27 M. Siwik, Glosa do Wyroku SA w Lublinie z dnia 27 września 2000 r., II AKa 180/00, „Palestra” 2003, z. 7-8, cyt. za: A. Zoll, w: idem (red.), Kodeks..., s. 932; por. Uzasadnienie uchwały SN z 24 maja 2005 r., I KZP 17/05, OSNKW 2005, nr 7-8, poz. 59, cyt. za: M. Szczepaniec, J. Zygmunt, op. cit., s. 154 .

28 M. Leonieni, Podjęcie postęowania umorzonego warunkowo przez sqd, „Problemy Wymiaru Sprawiedliwości” 1973, nr 2, s. 95.

${ }^{29}$ A. Zoll, Materialnoprawna..., s. 184-185; T. Kozioł, op. cit., s. 70; M. Leonieni, W. Michalski, op. cit., s. 69.

${ }^{30}$ A. Zoll, Materialnoprawna..., s. 185; M. Leonieni, W. Michalski, op. cit., s. 68-69, 91; eidem, Warunkowe umorzenie postepowania karnego $w$ świetle ustawy $i$ praktyki sqdowej, Warszawa 1972, s. 119-120; B. Kunicka-Michalska, Warunkowe umorzenie postepowania karnego w praktyce prokuratorskiej, „Studia Prawnicze” 1977, z. 4, s. 67. 
efektywność doprowadziła do wskazania źródeł jej braku oraz wskazania optymalnych sposobów naprawy sytuacji w postaci zaprezentowanych w artykule postulatów de lege ferenda.

dr Karol Juszka

Uniwersytet Jagielloński

karoljuszka@interia.pl

\section{EFFECTIVENESS OF THE INSTITUTION OF CONDITIONAL DISCONTINUATION OF CRIMINAL PROCEEDINGS IN PREPARATORY AND JURISDICTION PROCEEDINGS}

\section{Sum mary}

The aim of this article is to present the effectiveness of preparatory and jurisdiction proceedings in the application of conditional discontinuation of the criminal proceedings institution. The analysis has been based on factors that increase and reduce effectiveness of its application, results reported in literature, also in light of the amendments to the Polish criminal procedure of 27 September 2013 and results of own research. The proceedings that were the subject of the analysis were randomly selected from those carried out in court units within the jurisdiction of the Regional Court in Kraków between 1 July 2003 and 1 July 2009, and consisted of 405 cases. The issue in question will be analysed in this paper throughout all stages of criminal proceedings. 